\title{
KONTRIBUSI EKSPOR SEKTOR PERIKANAN DALAM PEREKONOMIAN NASIONAL: ANALISIS INPUT OUTPUT
}

\author{
Oleh: \\ Risna Yusuf dan Tajerin *
}

\begin{abstract}
Kajian ini bertujuan mengetahui sejauhmana kontribusi ekspor sektor perikanan "dalam arti luas" dalam perekonomian nasional, khususnya pada pertumbuhan output, pendapatan masyarakat dan penyerapan tenaga kerja. Kajian ini menggunakan data sekunder yaitu tabel Input Output tahun 2000 yang dikeluarkan oleh BPS. Kajian ini menggunakan metode analisis Input Output. Hasil kajian memperlihatkan bahwa kontribusi ekspor sub sektor industri pengolahan hasil perikanan dalam pembentukan output dan pendapatan masyarakat ternyata jauh lebih besar dibandingkan dengan sektor perikanan yaitu masingmasing 10,28\% dari Rp 102.264.263 juta; 5.55\% dari Rp. 28.721.949. Namun sebaliknya dalam penyerapan tenaga kerja, ternyata kontribusi ekspor sektor perikanan justru lebih besar dibandingkan dengan sub sektor industri pengolahan hasil perikanan sebesar $7,45 \%$ dari 2.685 .339 orang. Oleh karena itu diperlukan peran pemerintah secara lebih nyata dalam mendorong besaran multiplier effect melalui penciptaan lapangan kerja dari kegiatan ekspor sub sektor industri pengolahan hasil perikanan dengan cara menumbuhkan kegiatan usaha di sub sektor industri perikanan yaitu di sub sektor industri pengeringan dan penggaraman dan sub sektor industri pengolahan dan pengawetan ikan.
\end{abstract}

Kata Kunci: Ekspor, Perikanan, Perekonomian

Abstract: Export Contribution of Fisheries sector in National Economy: An Input Output Analysis. By: Risna Yusuf and Tajerin

The objective of the research is to assess the extent of export contribution of Fisheries sub sector and its products in National Economy, especially on output growth, social income and labor absorption. Secondary data of input output table 2000, which published by BPS was used in this study. The method of input output analysis was used. Results of the research indicate that export contribution of processed fish product industries on output growth and social income are higher than the fisheries sector, which are 10.28\% of Rp 102.264.26\% and 5.55\% of Rp 28.721.949, respectively. On the other hand, contribution of fisheries sector is higher than the one of processed fish product industries. Therefore, the government plays an important role to boost the multiplier effect on labor absorption of industrial fish processing by growing the activities on this sector; i.e. salted and dried fish and processed and preserved fish in terms of labor absorption.

Keyword: Export, Fisheries, Economy

\footnotetext{
* Peneliti Pada Balai Besar Riset Sosial Ekonomi Kelautan dan Perikanan, BRKP-DKP.

JI. KS TUBUN Petamburan VI Slipi Jakarta 10260. Telp. (021) 53650159
} 


\section{PENDAHULUAN}

Penerapan kebijakan orientasi ekspor telah diterapkan oleh banyak negara di dunia, baik negara-negara maju dan negara-negara industri baru (Newly Industrialized Countries, NICs) seperti Korea Selatan, Taiwan, China dan Singapura. Berkat kebijakan tersebut negara-negara tersebut menjadi kuat ekonominya karena terbukti mampu mendorong peningkatan ekspor secara pesat. Orientasi ekspor dianggap dapat mengarahkan kepada kondisi alokasi sumberdaya yang efisien, penggunaaan kapasitas produksi yang lebih besar, pencapaian skala ekonomi, memperbaiki teknologi sebagai upaya merespon persaingan di luar negeri serta memberikan kontribusi untuk meningkatkan pekerjaan di negara-negara surplus tenaga kerja (Balassa, 1976; Balassa et al., 1987). Negara-negara penganut kebijakan orientasi ekspor (outward oriented) lebih baik kinerja ekspornya dibanding dengan negara-negara yang tidak menganut kebijakan tersebut (inward oriented) (Bank Dunia, 1967 dalam Dodaro, 1991).

Indonesia sebagai negara yang berbasis sumberdaya alam, masih menggantungkan kegiatan ekspornya pada komoditas maupun produk yang dihasilkan dari sektor primer seperti tanaman bahan makanan, perkebunan, peternakan, kehutanan dan perikanan. Khusus komoditas atau produk perikanan Indonesia hingga saat ini masih memiliki variasi yang sangat terbatas dan jauh lebih rendah dibandingkan dengan negara tetangga seperti Thailand, Philipina bahkan terhadap Vietnam sekalipun. Padahal potensi perikanan Indonesia relatif lebih besar dibandingkan ketiga negara tersebut. Hal ini mengakibatkan daya saing ekspor komoditas maupun produk perikanan Indonesia dalam posisi yang tidak menguntungkan dibanding negara-negara lain. Kondisi daya saing tersebut tentunya menjadi semakin buruk lagi bila ke depan kurang mendapat dukungan nyata dari pemerintah, khususnya melalui berbagai kemudahan dan upaya-upaya yang mendorong terciptanya iklim yang kondusif bagi peningkatan kinerja ekspor perikanan secara menyeluruh.

Kajian ini bertujuan mengetahui sejauhmana kontribusi ekspor sektor perikanan dalam perekonomian nasional, khususnya pada pertumbuhan output, pendapatan masyarakat dan penyerapan tenaga kerja. Hasil kajian ini diharapkan dapat berguna sebagai bahan masukan bagi perumusan kebijakan yang terkait dengan peningkatan kinerja ekspor perikanan.

\section{METODE}

\section{Landasan Teori}

Analisis data dalam kajian ini dilakukan dengan pendekatan model input-output (I-O). Dalam prakteknya, model I-O merupakan salah satu alat analisis yang banyak digunakan dalam berbagai disiplin ilmu, seperti: ekonomi, geografi, regional science dan sebagainya. Analisis I-O ini pertama kali dikembangkan oleh Professor Leontief dari Universitas Havard yang berhasil menyusun tabel I-O Amerika Serikat. Model I-O tersebut merupakan penyederhanaan dari keseimbangan umum (general equilibrium) yang dikemukakan oleh Leon Walras (Miller and Blair, 1985). Oleh Leontief persamaan rumit dari teori keseimbangan tersebut disederhanakan sehingga menjadi model yang memungkinkan untuk diterapkan secara empiris.

Dalam proses penyusunan tabel I-O diperlukan suatu tahapan untuk mengelompokkan barang dan jasa ke dalam kelompok-kelompok tertentu. Proses pengelompokkan barang dan jasa ini dikenal sebagai proses klasifikasi sektor. Dalam praktek penyusunan tabel I-O, klasifikasi sektor harus dilakukan pada tahap awal.

Sesuai dengan namanya, model I-O pada dasarnya berisikan gambaran mengenai 
saling keterkaitan antara suatu sektor yang digunakan sebagai input, baik untuk menghasilkan output sektor itu sendiri maupun sektor lain. Keterkaitan antara input dan output tersebut secara sederhana dapat digambarkan dalam tabel transaksi seperti tertera pada Tabel 1.

Sesuai dengan azas keseimbangan umum yang melandasi konsep I-O, output suatu sektor seluruhnya habis digunakan oleh sektor lainnya (termasuk oleh sektornya sendiri) baik sebagai input antara untuk suatu proses produksi lebih lanjut maupun permintaan akhir, misalnya untuk konsumsi rumah tangga dan pemerintah, investasi atau ekspor (Nazara, 1997). Dengan demikian total
Total output suatu sektor sama dengan total input sector tersebut: $\mathrm{X}_{i}=\mathrm{X}_{j}$ (untuk $i=j$ ). Dalam neraca produksi, keuntungan adalah selisih antara nilai penjualan dengan biaya produksi. Biaya produksi dalam hal ini terdiri dari atas dua bagian utama, yaitu: pertama, biaya bahan baku, termasuk untuk jasa (misalnya angkutan, perbankan dan sebagainya); kedua, biaya untuk upah dan gaji, termasuk pajak. Biaya yang dikeluarkan untuk memperoleh barang dan jasa tersebut dalam table $\mathrm{IO}$ identik dengan input antara, sedangkan upah dan gaji, keuntungan dan pajak identik dengan input primer (nilai tambah bruto). Dengan demikian total input suatu sektor adalah jumlah seluruh input antara

Tabel 1. Tabel Transaksi Input Output Antar Sektor

Table 1. Input Output Transaction Table According to Sectors

\begin{tabular}{|c|c|c|c|c|c|c|c|}
\hline \multirow{2}{*}{$\begin{array}{l}\text { Sektor Penjual } \\
\text { Seller Sector }\end{array}$} & \multicolumn{4}{|c|}{$\begin{array}{c}\text { Sektor Pembeli } \\
\text { Buyer Sector }\end{array}$} & \multirow{2}{*}{$\begin{array}{l}\text { Permintaan } \\
\text { Akhir } \\
\text { Final Demand }\end{array}$} & \multirow{2}{*}{\multicolumn{2}{|c|}{$\begin{array}{l}\text { Total } \\
\text { Output } \\
\text { Total } \\
\text { Output }\end{array}$}} \\
\hline & 1 & 2 & $\cdots$ & N & & & \\
\hline 1 & $x_{11}$ & $x_{12}$ & $\ldots$ & $x_{1 n}$ & $\mathrm{~F}$ & & $X_{1}$ \\
\hline 2 & $x_{21}$ & $x_{22}$ & $\ldots$ & $x_{2 n}$ & $\mathrm{~F}$ & & $X_{2}$ \\
\hline$\ldots$ & $\cdots$ & $\cdots$ & $\cdots$ & $\cdots$ & & & $\dddot{x}$ \\
\hline Input Primer & $\begin{array}{l}x_{n 1} \\
V_{1}\end{array}$ & $\begin{array}{l}\mathrm{x}_{\mathrm{n} 2} \\
\mathrm{~V}_{2}\end{array}$ & $\ldots$ & $\begin{array}{l}x_{n} \\
V_{n}\end{array}$ & & & $\lambda_{n}$ \\
\hline Total Input & $X_{1}$ & $X_{2}$ & $\ldots$ & $X_{n}$ & & & \\
\hline
\end{tabular}

Sumber: Perserikatan Bangsa-Bangsa (1988).

Source: United Nation (1998)

Keterangan/Remarks :

xij = Besaran Output dari Sektor i untuk Digunakan sebagai Input oleh Sektor j/Output of Sector i as Input by Sectorj

$\mathrm{X}$ = Total Output dari sektor $\mathrm{I} /$ Total Output of Sector $i$

$\mathrm{Xj}=$ Total Input dari Sektor $\mathrm{j} /$ Total Input of Sector $j$

$\mathrm{Fi}=$ Besaran Permintaan Akhir Terhadap Sektor I/Final Demand of Sector I

output sector $i\left(\mathrm{X}_{i}\right)$ adalah jumlah output sektor $i$ yang digunakan sebagai input oleh sektor $j(j$ $=1,2, \ldots n)$ ditambah dengan permintaan akhir, yang dalam bentuk notasi matriks persamaan (1) tersebut dapat ditulis sebagai:

$\sum x_{i j}+F_{i}=X_{i} ; \mathrm{i}=1, \ldots, \mathrm{n}$

dimana:

$x_{i j}=$ banyaknya output sektor $i$ yang digunakan sebagai input oleh sektor $j$

$\mathrm{F} i=$ permintaan akhir terhadap output sektor $i$ $\mathrm{X}_{i}=$ total output sektor $i$ ditambah input primer, yang dalam bentuk notasi matriks ditulis sebagai:

$\sum x_{i j}+V_{j}=X_{j} ; j=1, \ldots \ldots, \mathrm{n}$

dimana:

xij = banyaknya output sektor $i$ yang digunakan sebagai input oleh sektor $j$

$\mathrm{V}_{i}=$ input primer (nilai tambah) sektor $j$

$\mathrm{X}_{j}=$ total output sektor $j$

Aliran antara kegiatan usaha dari suatu sektor dengan sektor lainnya dapat ditransformasikan menjadi koefisien-koefisien 
yang mencerminkan hubungan secara teknis di antara sektor-sektor yang saling berinteraksi atau disebut sebagai koefisien-koefisien teknis (Miller and Blair, 1985; Nazara, 1997) dengan asumsi bahwa: (1) jumlah berbagai pembelian adalah tetap untuk sebuah tingkat total keluaran (dengan kata lain, tidak ada economic of scale); dan (2) tidak ada kemungkinan substitusi antara sebuah bahan baku masukan dengan bahan baku masukan lainnya (dengan kata lain, bahan baku masukan dibeli dalam proporsi yang tetap). Berdasarkan persamaan (1) atau persamaan (2) dan dengan menggunakan asumsi bahwa $\mathrm{X}_{i}=\mathrm{X}_{j}$ (total input sama dengan total output), sehingga menjadi :

$$
a_{i j}=x_{i j /} / X_{i} \text { atau } x_{i j}=a_{i j} X_{i}
$$

dengan memasukkan persamaan (4) ke dalam persamaan (2), dalam bentuk matriks didapat:

$$
\sum a_{i j} X_{i}+F_{i}=X_{i} \text { atau } A X_{i j}+F_{i}=X_{i}
$$

dengan memanipulasi, persamaan (6) didapat hubungan dasar dari Tabel IO sebagai berikut:

$$
(I-A)^{-1} F=X
$$

Dimana $(I-A)^{-1}$ dinamakan sebagai matriks kebalikan Leontief. Matriks ini merangkum seluruh dampak dari perubahan produksi suatu sektor terhadap total produksi sektorsektor lainnya ke dalam koefisien-koefisien yang disebut sebagai pengganda yang merupakan angka-angka yang terlihat di dalam matriks $(I-A)-1$.

Dari besaran nilai pengganda tersebut dapat diketahui sejauhmana peranan sub sektor perikanan dan industri pengolahan hasil perikanan dalam perekonomian nasional. Angka pengganda dalam hal ini berupa suatu koefisien yang menyatakan kelipatan dampak langsung dan tidak langsung dari peningkatan permintaan akhir suatu sektor sebesar satu unit terhadap produksi total semua sektor (Miller dan Blair, 1985). Pada intinya, analisis angka pengganda berupaya melihat apa yang terjadi terhadap variabel-variabel endogen tertentu apabila terjadi perubahan variable- variabel eksogen, seperti permintaan akhir di dalam perekonomian yang meliputi: konsumsi rumah tangga, pengeluaran pemerintah, pembentukan modal tetap (investasi), perubahan stok dan ekspor (Nazara, 1997).

\section{Jenis dan Sumber Data}

Data yang digunakan dalam kajian ini adalah data sekunder dari buku Tabel InputOuput Tahun 2000 yang disusun oleh Badan Pusat Statistik (1994, 1999, 2004ª) berupa "tabel transaksi domestik atas dasar harga produsen dalam satuan jutaan rupiah". Untuk dapat merekam kontribusi ekspor sub sektor perikanan dan industri pengolahan hasil perikanan, dalam kajian ini digunakan Tabel Input-Output menurut klasifikasi $175 \times 175$ sektor untuk tahun 2000. Selanjutnya dari tabel tersebut diklasifikasi kembali (reklasifikasi) dengan menggunakan teknik agregasi, sehingga menjadi matriks dengan klasifikasi $9 \times 9$ sektor, seperti tertera pada Tabel 2.

\section{Metode Analisis Data}

Dalam kajian ini, untuk menganalisis kontribusi ekspor sub sektor perikanan dan industri pengolahan perikanan dalam perekonomian nasional dilakukan dengan menggunakan pendekatan model input-output berdasarkan persamaan yang dapat diturunkan dari tabel domestik di atas adalah:

- Persamaan menurut baris,

$$
X_{i}^{d}=x_{i j}^{d}+F_{i}^{d}
$$

- Persamaan menurut kolom,

dimana:

$$
X_{j}^{d}=x_{i j}^{d}+M_{j}+V_{j}
$$

$x_{i j}^{d}=$ input antara sektor ke-j yang berasal dari produksi domestik sektor ke- $i$

$F_{i}^{d}=$ permintaan akhir yang berasal dari produksi domestik sektor ke- $i$

$X_{i}^{d}=$ output domestik sektor ke- $i$, untuk $i=1$, $2, \ldots, \mathrm{n}$

$X_{j}^{d}=$ input domestik sektor ke-j, untuk $\mathrm{j}=1,2$, $\ldots, \mathrm{n}$ 
Tabel 2. Pengklasifikasian Kembali Sektor-Sektor dari Tabel Input-Output yang digunakan menjadi Klasifikasi Matriks Ukuran 9 x 9 Sektor

Table 2. Sectors Reclassification from Input Output Table to 9 × 9 Matrix Classification

\begin{tabular}{|c|c|c|c|c|}
\hline \multirow{2}{*}{$\begin{array}{l}\text { Sektor I } \\
\text { Sector }\end{array}$} & \multirow{2}{*}{$\begin{array}{l}\text { Deskripsi / } \\
\text { Description }\end{array}$} & \multicolumn{3}{|c|}{$\begin{array}{l}\text { Sektor-Sektor dalam Tabel Input-Output I } \\
\text { Sectors in Input Output Table }\end{array}$} \\
\hline & & 1990 & 1995 & 2000 \\
\hline 1 & $\begin{array}{l}\text { Pertanian Non Perikanan/ Agriculture } \\
\text { Non Fisheries }\end{array}$ & $1-28$ & $1-31$ & $1-30$ \\
\hline 2 & $\begin{array}{l}\text { Perikanan Primer/Primary Fisheries: } \\
\text { - Sub Sektor Perikanan Laut dan Hasil } \\
\text { Perairan Laut Lainnya/ Sub Sector of } \\
\text { Marine Fisheries and Its Result }\end{array}$ & 29 & $\left.32 ; 34 \mathrm{~L}_{90}{ }^{*}\right)$ & $31 ; 33 \mathrm{~L}_{00}{ }^{* * *}$ \\
\hline 3 & $\begin{array}{l}\text { - Sub Sektor Perikanan Darat dan Hasil } \\
\text { Perairan Darat Lainnya/Sub Sector of } \\
\text { Fresh Water Fisheries and Its Result }\end{array}$ & 30 & $33 ; 34 D_{90}{ }^{* *}$ & $32 ; 33 \mathrm{D}_{00}{ }^{* * * *}$ \\
\hline & $\begin{array}{l}\text { Perikanan Sekunder/ Secondary } \\
\text { Fisheries: }\end{array}$ & & & \\
\hline 4 & $\begin{array}{l}\text { - Sub Sektor Industri Pengeringan dan } \\
\text { Penggaraman Ikan dan Biota Perairan } \\
\text { Lainnya/ Sb Sector Drying and Salting } \\
\text { Processing Industries }\end{array}$ & 31 & 53 & 53 \\
\hline 5 & $\begin{array}{l}\text { - Sub Sektor industri Pengolahan dan } \\
\text { Pengawetan Ikan dan Biota Perairan } \\
\text { Lainnya/Sub Sector Processing and } \\
\text { Preserving Industries }\end{array}$ & 48 & 54 & 54 \\
\hline 6 & $\begin{array}{l}\text { Pertambangan dan Penggalian/ Mining } \\
\text { and Quarrying }\end{array}$ & $32-34$ & $36-48$ & $35-48$ \\
\hline 7 & $\begin{array}{l}\text { Industri Pengolahan Hasil Pertanian Non } \\
\text { Perikanan/ Agriculture Non Fisheries } \\
\text { Processing Industries }\end{array}$ & $\begin{array}{r}47-47 \\
49-83\end{array}$ & $\begin{array}{r}49-52 \\
55-91\end{array}$ & $\begin{array}{r}49-52 \\
55-93\end{array}$ \\
\hline 8 & $\begin{array}{l}\text { Industri Pengolahan Lainnya/ Other } \\
\text { Processing Industries }\end{array}$ & $84-131$ & $92-139$ & $94-141$ \\
\hline 9 & Jasa dan Lainnya/ Service and Others & $132-161$ & $35 ; 140-172$ & $34 ; 142-175$ \\
\hline
\end{tabular}

Keterangan:

*) Proporsi Output Sektor 34 (udang) untuk Sektor 29 Sebesar 54,1\% yang Berasal dari Udang Hasil Tangkapan di Laut pada Tahun 1995 (BPS, 2004b)

**) Proporsi Output Sektor 34 (udang) untuk Sektor 30 Sebesar 45,9\% yang Berasal dari Udang Hasil Budidaya Tambak dan Tangkapan di Perairan Umum pada Tahun 1995 (BPS, 2004b)

***) Proporsi Output Sektor 34 (udang) untuk Sektor 29 Sebesar 54,5\% yang Berasal dari Udang Hasil Tangkapan di Laut pada Tahun 2000 (BPS, 2004b)

${ }^{* * * *}$ ) Proporsi Output Sektor 34 (udang) untuk Sektor 30 Sebesar 54,5\% yang Berasal dari Udang Hasil Budidaya Tambak dan Tangkapan di Perairan Umum pada Tahun 2000 (BPS, 2004b)

Remarks:

*) Output Proportion of 34 Sector (shrimp) for 29 Sector is 54,1\% from Shrimp from <arine in 1995 (BPS, 2004b)

**) Output Proportion of 34 Sector (shrimp) for 30 Sector is 45,9\% from Shrimp from Brackiswater Pond and in Land Water in 1995 (BPS, 2004b)

***) Output Proportion of 34 Sector (shrimp) for 29 Sector is 54,5\% from Marine in 2000 (BPS, 2004b)

****) Output Proportion of 34 Sector (shrimp) for 30 Sector is 54,5\% from Brachkiswater Pond and Inland in 2000 (BPS, $2004 \mathrm{~b}$ ). 
$M_{j}=$ impor sektor ke- $j$, untuk $j=1,2, \ldots, \mathrm{n}$

$V_{j} \quad=$ nilai tambah sektor ke- $j$, untuk

$$
j=1,2, \ldots, \mathrm{n}
$$

Isian sepanjang baris pada Tabel 1 memperlihatkan bagaimana output dari suatu sektor dialokasikan, yaitu sebagian untuk memenuhi permintaan antara dan sebagian lainnya untuk memenuhi permintaan akhir. Dalam model I-O, produksi yang dihasilkan oleh suatu sektor akan mempunyai dua jenis efek terhadap sektor produksi lainnya di dalam perekonomian. Pertama, hubungan keterkaitan dari suatu sektor terhadap sektorsektor lainnya yang produksinya digunakan sebagai input oleh sektor tersebut atau yang disebut sebagai daya penyebaran atau keterkaitan ke belakang. Kedua, hubungan keterkaitan dari suatu sektor terhadap sektorsektor lainnya yang produksinya digunakan sebagai input oleh sektor-sektor lainnya atau yang disebut derajat kepekaan atau keterkaitan ke depan. Hubungan keterkaitan tersebut dapat dijelaskan dengan menggunakan koefisien teknis dan matriks kebalikan Leontief.

Koefisien teknis merupakan proporsi input antara yang berasal dari sektor ke- $i$ terhadap total input sektor ke-j yang dirumuskan menjadi:

$$
a_{i j}=\frac{x_{i j}}{X_{j}}
$$

dimana:

$$
\begin{aligned}
a_{i j}= & \text { unsur-unsur matriks koefisien teknis } \\
& \text { sektor } j \\
x_{i j}= & \text { banyaknya ouput sektor } i \text { yang } \\
& \text { digunakan sebagai input oleh sektor } \\
X_{i j}= & \text { total input sektor } j
\end{aligned}
$$

Jika nilai $a_{i j}$ untuk seluruh sektor dapat dihitung, maka dapat disusun matriks koefisien teknis (A) yang merupakan dasar untuk perhitungan efek pengganda yang menjadi salah satu inti dari analisis I-O. Efek pengganda diperoleh dengan mensubstitusikan persamaan (1) ke dalam persamaan (3) sehingga susunan matriks-nya dapat ditulis kembali sebagai berikut:

$$
X=(I-A)^{-1} F^{d}
$$

dimana:

$$
\begin{array}{ll}
I & =\text { matriks identitas } \\
A & =\text { matriks koefisien teknis } \\
F^{d}= & \text { matriks permintaan akhir } \\
& \text { domestik, } F^{d}=F-M \\
(I-A)^{-1}= & \text { matriks kebalikan Leontief }
\end{array}
$$

\section{Kontribusi Ekspor dalam Pertumbuhan Output}

Dalam model I-O output hubungan timbal balik dengan permintaan akhir terhadap output tersebut. Ini berarti bahwa jumlah output yang dapat diproduksi tergantung dari jumlah permintaan akhirnya. Pengaruh perubahan output akibat perubahan permintaan akhir dari dicari dengan formulasi berikut :

$$
X F D=(I-A)^{-1} F^{d}
$$

\section{Kontribusi Ekspor dalam Pendapatan Masyarakat}

Nilai Tambahan Bruto (NTB) adalah input primer yang merupakan bagian dari input secara keseluruhan. Sesuai dengan asumsi IO maka terdapat hubungan linier antara NTB dengan output, artinya kenaikan atau penurunan output akan diikuti secara proporsional oleh kenaikan atau penurunan NTB. Hubungan ini dapat dicari dengan menggunakan formulasi :

$$
v=v X
$$

dimana :

$\mathrm{V}=$ matriks NTB

$\mathrm{v}=$ matriks diagonal koefisien NTB

$\mathrm{X}=$ matriks output

\section{Kontribusi Ekspor dalam Penyerapan Tenaga Kerja}

Untuk melihat dampak perubahan 
permintaan akhir terhadap kebutuhan tenaga kerja dapat dicari dengan menggunakan formulasi :

$$
L=l(I-A)^{-1} F^{d}
$$

dimana :

$$
\begin{aligned}
L= & \text { kebutuhan tenaga kerja yang } \\
& \text { dipengaruhioleh permintaan akhir } \\
= & \text { Matriks diagonal koefisien tenaga } \\
& \text { kerja }
\end{aligned}
$$

\section{HASIL DAN PEMBAHASAN}

\section{Kontribusi Ekspor Terhadap Pertumbuhan Output}

Dari Tabel 3 dan Lampiran 1 terlihat bahwa pada tahun 2000 kontribusi ekspor dari keseluruhan sektor dalam pembentukan output perekonomian nasional adalah sebesar Rp.102.264.263 juta, sedangkan kontribusi ekspor perikanan primer (perikanan laut dan perikanan darat) dan perikanan sekunder (industri pengeringan dan penggaraman ikan dan industri pengolahan dan pengawetan ikan ) pada tahun yang sama masing-masing baru mencapai sebesar $5,18 \%$ dan $10,28 \%$ dari kontribusi keseluruhan sektor. Secara riil, kontribusi ekspor perikanan primer dalam pembentukan output perekonomian nasional adalah sebesar Rp. 5.293.860 juta, sedangkan perikanan sekunder sebesar Rp. 10.515.921 juta. Dengan demikian berdasarkan perbandingan nilai kontribusi ekspor ternyata perikanan sekunder memberikan kontribusi ekspor yang lebih besar dalam pembentukan output total dibandingkan dengan perikanan primer.

Selanjutnya apabila dilihat secara lebih rinci, ternyata pada perikanan primer, perikanan laut memiliki kontribusi ekspor lebih besar yaitu sebesar Rp. 4.661.335 juta dibandingkan perikanan darat yang memiliki kontribusi ekspor sebesar Rp. 632.525 juta.

Berdasarkan nilai kontribusi ekspor tersebut, ternyata secara relatif perikanan laut memberikan kontribusi ekspor yang lebih penting dalam pembentukan output dibandingkan dengan perikanan darat. Di lain pihak perikanan sekunder, ternyata secara

Tabel 3. Kontribusi Ekspor Perikanan Primer, Perikanan Sekunder dan Keseluruhan Sektor Terhadap Pembentukan Output Ekonomi Nasional,2000

Table 3. Export Contribution of Primary, Secondary Fisheries and All Sectors to National Economy Output Growth, 2000

\begin{tabular}{lcr}
\hline \multicolumn{1}{c}{$\begin{array}{c}\text { Uraian / } \\
\text { Description }\end{array}$} & $\begin{array}{c}\text { Jumlah Output } \\
\text { (Juta Rupiah) / } \\
\text { Output (Million } \\
\text { Rupiah) }\end{array}$ & $\begin{array}{c}\text { Persentase / } \\
\text { Presenting } \\
\text { (\%) }\end{array}$ \\
\hline 1. Perikanan Primer/Primary Fisheries & $\mathbf{5 . 2 9 3 . 8 6 0}$ & $\mathbf{5 , 1 8}$ \\
- Perikanan Laut/ Marine Fisheries & 4.661 .335 & 4,56 \\
- Perikanan Darat/Fresh Water Fisheries & 632.525 & 0,62 \\
2. Perikanan Sekunder / Secondary Fisheries & 10.515 .921 & $\mathbf{1 0 , 2 8}$ \\
- Industri Pengeringan dan Penggaraman Ikan/ & 1.336 .809 & 1,31 \\
$\quad$ Drying and Salting Processing Industries & & 8,98 \\
- Industri Pengolahan dan Pengawetan & 9.179 .112 & 100 \\
Ikan/Processing and Preserving Industries & & \\
3. Keseluruhan Sektor / All Sector & 102.264 .263 & \\
\hline
\end{tabular}


relatif secara relatif industri pengolahan dan pengawetan ikan memiliki kontribusi ekspor yang lebih penting dalam pembentukan output dibandingkan dengan industri pengeringan dan penggaraman.

\section{Kontribusi Ekspor Terhadap Pendapatan Masyarakat}

Dari Tabel 4 dan Lampiran 2 terlihat bahwa besarnya nilai kontribusi ekspor dari keseluruhan sektor dalam perolehan pendapatan masyarakat secara nasional adalah sebesar Rp. 28.721 .949 juta. Sedangkan dari perikanan primer dan perikanan sekunder pada tahun yang sama masing-masing memberikan kontribusi ekspor masing-masing baru mencapai sebesar 3,63\% dan sebesar $5,55 \%$. Secara riil, kontribusi ekspor perikanan primer (perikanan laut dan perikanan darat) dalam perolehan pendapatan masyarakat secara nasional adalah sebesar Rp. 1.042.724 juta, sedangkan dari perikanan sekunder (industri pengeringan dan penggaraman ikan dan industri pengolahan dan pengawetan ikan) sebesar Rp. 1.594.282 juta. Dengan demikian berdasarkan perbandingan nilai kontribusi ekspor tersebut ternyata secara relatif perikanan sekunder memiliki kontribusi ekspor yang lebih besar dalam pendapatan masyarakat dibandingkan dengan perikanan primer.

Selanjutnya apabila dilihat secara lebih rinci, ternyata pada perikanan primer, perikanan laut memiliki kontribusi ekspor lebih besar yaitu sebesar 921.027 dibandingkan perikanan darat yang memiliki kontribusi ekspor sebesar 121.697. Dari nilai kontribusi tersebut secara relatif perikanan laut memiliki kontribusi ekspor dalam perolehan pendapatan masyarakat yang lebih penting dibandingkan dengan perikanan darat, sedangkan di perikanan sekunder, ternyata secara relatif berdasarkan nilai kontribusi ekspor, secara relatif industri pengolahan dan pengawetan ikan memiliki kontribusi ekspor yang lebih penting dalam pendapatan masyarakat dibandingkan dengan industri pengeringan dan penggaraman.

\section{Kontribusi Ekspor Terhadap Penyerapan Tenaga Kerja}

Dari Tabel 5 atau Lampiran 3 terlihat

Tabel 4. Kontribusi Ekspor Perikanan Primer, Perikanan Sekunder dan Keseluruhan Sektor terhadap Pendapatan Nasional,2000

Table 4. Export Contribution of Primary, Secondary Fisheries and All Sectors to National Income, 2000

\begin{tabular}{lrr}
\hline Uraian/ & Jumlah (Juta Rp)/ & \multicolumn{1}{c}{$\begin{array}{c}\text { Persentase (\%)/ } \\
\text { Presentage (\%) }\end{array}$} \\
\hline 1. Perikanan Primer/Primary Fisheries & Amount (Million Rp) & $\mathbf{3 , 6 3}$ \\
- Perikanan Laut/Marine Fisheries & $\mathbf{1 . 0 4 2 . 7 2 4}$ & 3,21 \\
- Perikanan Darat/ Fresh Water Fisheries & 921.027 & 0,42 \\
2. Perikanan Sekunder/Secondary Fisheries & 121.697 & $\mathbf{5 , 5 5}$ \\
- Industri Pengeringan dan Penggaraman Ikan/ & & 0,69 \\
$\quad$ Drying and salting Fisheries Industries & $\mathbf{1 . 5 9 4 . 2 8 2}$ & 4,86 \\
- Industri Pengolahan dan Pengawetan Ikan/ & 198.119 & \\
$\quad$ Processing and Preserving Fisheries Industries & 1.396 .163 & 100,00 \\
3. Keseluruhan Sektor/All Sectors & & \\
\hline
\end{tabular}




\section{Tabel 5. Kontribusi Ekspor Perikanan Primer, Perikanan Sekunder dan Keseluruhan Sektor terhadap Penyerapan Tenaga Kerja Nasional,2000}

Table 5. ExportContribution of Primary, Secondary Fisheries and All Sectors to Absorption National of Labor, 2000

\begin{tabular}{lrr}
$\begin{array}{c}\text { Uraian I } \\
\text { Description }\end{array}$ & $\begin{array}{r}\text { Jumlah (Orang) I } \\
\text { Amount (Person) }\end{array}$ & $\begin{array}{c}\text { Persentase (\%) I } \\
\text { Presentage (\%) }\end{array}$ \\
\hline 1. Perikanan Primer/Primary Fisheries & $\mathbf{2 0 0 . 1 1 0}$ & $\mathbf{7 , 4 5}$ \\
- Perikanan Laut/Marine Fisheries & 188.058 & 7,00 \\
- Perikanan Darat/Fresh Water Fisheries & 12.052 & 0,45 \\
2. Perikanan Sekunder/Secondary Fisheries & 32.649 & $\mathbf{1 , 2 2}$ \\
- Industri Pengeringan dan Penggaraman Ikan/ & 2.113 & 0,08 \\
$\quad$ Drying and Salting Fisheries Industries & 30.536 & 1,14 \\
- Industri Pengolahan dan Pengawetan Ikan/ & & \\
Processing and Preserving Fisheries Industries & 2.685 .339 & 100,00 \\
3. Keseluruhan Sektor/ All Sectors & & \\
\hline
\end{tabular}

Sumber: Hasil Pengolahan Tabel Input Output,2000

Source : Processing Result of Input Output Table 2000

bahwa besarnya kontribusi ekspor dari keseluruhan sektor dalam penyerapan tenaga kerja adalah sebanyak 2.685.339 orang. Pada tahun yang sama kontribusi ekspor perikanan primer (perikanan laut dan perikanan darat) dan perikanan sekunder (industri pengeringan dan penggaraman ikan dan industri pengolahan dan pengawetan ikan) dalam penyerapan tenaga kerja baru adalah sebesar $7,45 \%$ dan $1,22 \%$. Secara riil kontribusi perikanan primer dalam penyerapan tenaga kerja adalah sebanyak 200.110 orang yang terdiri dari sebanyak 188.058 orang dari perikanan laut dan sebanyak 12.052 orang dari perikanan darat. Sedangkan dari perikanan sekunder sebesar 32.649 orang yang terdiri dari sebanyak 2.113 orang dari industri pengeringan dan penggaraman ikan dan biota perairan lainnya, dan sebanyak 30.536 orang dari industri pengolahan dan pengawetan ikan dan biota perairan lainnya. Berdasarkan perbandingan nilai kontribusi ekspor ternyata secara relatif perikanan sekunder memiliki kontribusi ekspor yang lebih besar dalam penyerapan tenaga kerja dibandingkan dengan perikanan primer.
Dengan demikian, berdasarkan nilai kontribusi ekspor tersebut, secara relatif perikanan primer memberikan kontribusi dalam penyerapan tenaga kerja yang lebih besar dibandingkan perikanan sekunder. Selanjutnya apabila dilihat lebih rinci, ternyata untuk perikanan primer secara relatif kontribusi ekspor perikanan laut dalam penyerapan tenaga kerja lebih besar dibandingkan perikanan darat, sedangkan untuk perikanan sekunder ternyata secara relatif kontribusi ekspor industri pengolahan dan pengawetan ikan dalam penyerapan tenaga kerja lebih besar dibandingkan dengan industri pengeringan dan penggaraman ikan.

\section{KESIMPULAN DAN IMPLIKASI KEBIJAKAN}

\section{Kesimpulan}

Kontribusi ekspor perikanan primer (perikanan laut dan perikanan darat) dan perikanan sekunder (industri pengeringan dan penggaraman ikan dan industri pengolahan dan pengawetan ikan) dalam pembentukan output, pendapatan masyarakat dan 
penyerapan tenaga kerja secara keseluruhan tergolong cukup besar. Secara relatif kontribusi ekspor perikanan sekunder dalam pembentukan output dan pendapatan masyarakat jauh lebih besar dibandingkan dengan perikanan primer. Dari kontribusi ekspor keseluruhan sektor terhadap pembentukan output perekonomian nasional sebesar Rp. 102.264.263 juta, kegiatan ekspor perikanan sekunder menyumbang sebesar $10.28 \%$, sedangkan perikanan primer sebesar $5,18 \%$. Sementara itu, dari kontribusi ekspor keseluruhan sektor terhadap pendapatan nasional sebesar Rp. 28.721.949 juta, kegiatan ekspor perikanan sekunder menyumbang sebesar $5,55 \%$, sedangkan perikanan primer sebesar 3,63\%. Sebaliknya untuk kontribusi ekspor dalam penyerapan tenaga kerja dari perikanan sekunder ternyata lebih rendah dibandingkan perikanan primer. Dari kontribusi ekspor keseluruhan sektor terhadap penyerapan tenaga kerja nasional sebanyak 2.685.339 orang (tenaga kerja), kegiatan ekspor perikanan sekunder menyumbang sebesar $1,22 \%$, sedangkan dari perikanan primer sebesar $7,45 \%$.

\section{Implikasi Kebijakan}

Pembangunan ekonomi suatu sektor akan lebih baik bila sub sektor sekunder dari sektor tersebut memiliki perkembangan yang lebih baik dibanding dengan sub sektor primernya. Mengingat bahwa kontribusi ekspor dari sub sektor industri pengeringan dan penggaraman ikan dan sub sektor industri pengolahan dan pengawetan ikan (sebagai sub sektor sekunder) dalam penyerapan tenaga kerja yang lebih rendah dibandingkan dengan perikanan laut dan perikanan darat (sebagai sektor primer), maka diperlukan peran pemerintah secara lebih nyata dalam mendorong besaran multiplier effect dalam penyerapan tenaga kerja dari perikanan sekunder, meskipun kontribusinya dalam pembentukan output dan pendapatan masyatakat jauh lebih besar dibandingkan dengan perikanan primernya.
Untuk mendorong multiplier effect tersebut, upaya yang dapat dilakukan oleh pemerintah adalah dengan cara menumbuhkan kegiatan usaha industri yang berbasis perikanan sekunder (seperti industri pengeringan dan penggaraman ikan dan industri pengolahan dan pengawetan ikan) namun dengan tidak melupakan pentingnya meningkatkan peranan sektor perikanan primernya. Hal ini dianggap penting karena demi menjaga keberlangsungan usaha dari perikanan primer dan perikanan sekunder yang terintegrasi secara baik dalam suatu sistem agribisnis perikanan. Sehingga diharapkan dengan kegiatan usaha di industri pada perikanan sekunder yang terintegrasi dengan perikanan primernya tersebut pada gilirannya dapat menciptakan lapangan kerja yang tinggi, terutama melalui peningkatan investasi dan ekspor secara nyata..

\section{DAFTAR PUSTAKA}

Balassa, B. 1976. Export \& Economic Growth Journal of Development Economics North-Holland \& Publishing Company. No.5.p: 158-189.

Balassa, B., Voloukadis, E. \& Sylaktos., 1987. The Determinant of Export Supply and Export Demand in two Developing Countries, Greece and South Korea. International Economic Journal. 3 (1): 134-146.

Biro Pusat Statistik. 1994. Tabel Input-Output Indonesia 1990. Jilid I, II dan III. Biro Pusat Statistik. Jakarta: BPS.

Biro Pusat Statistik. 1999. Tabel Input-Output Indonesia 1995. Jilid I, II dan III. Biro Pusat Statistik. Jakarta: BPS.

Badan Pusat Statistik. 2004 ${ }^{\mathrm{a}}$. Tabel InputOutput Indonesia 2000. Jilid I, II dan III. Jakarta : BPS.

Badan Pusat Statisitik. 2004 ${ }^{\text {b }}$ Indikator Ekonomi Makro Sektor Kelautan dan Perikanan Tahun 1990 - 2000. Buku I. Jakarta: BPS. 
Dodaro, S. 1991. Comparative Advantages, Trade and Growth : Export-Led Growth Revisited, World Development, 19 (9): 1153-1165.

Miller, E.R. and Blair, D.P. 1985. Input-Ouput Analysis: Foundations and Extentions. Precentice Hall Inc. 464 pp.

Nazara, S. 1997. Analisis Input Output. Jakarta: Lembaga Penerbit Fakultas Ekonomi Universitas Indonesia. 130 hal.
Perserikatan Bangsa-Bangsa, 1988. Studi dalam Metoda. Tabel Input Output dan Analisis. Seri F No.14, Rev.1. Penerjemah: Soeheba Kramadibarata dan Sri Edi Swasono. Pendamping: Rudiansyah. Jakarta: Universitas Indonesia Press. 256 hal.

\section{LAMPIRAN / Appendix}

\section{Lampiran1. Kontribusi Ekspor Terhadap Pembentukan Output Tahun 2000} Appendix 1. Expor Contribution to Output Growth in 2000

\begin{tabular}{lcr}
\hline \multicolumn{1}{c}{ Deskripsi / Description } & \multicolumn{1}{c}{$\begin{array}{c}\text { Sektor / } \\
\text { Sector }\end{array}$} & $\begin{array}{l}\text { Jumlah output / } \\
\text { Amount of Output } \\
\text { (Juta Rp) / (Rp Million) }\end{array}$ \\
\hline $\begin{array}{l}\text { Pertanian Non Perikanan / Agriculture Non isheries } \\
\text { Perikanan Laut dan Hasil Perairan Laut lainnya / }\end{array}$ & $\mathbf{1}$ & $57,898,992$ \\
$\begin{array}{l}\text { Marine Fisheries and Its Result } \\
\text { Perikanan Darat dan Hasil Perairan Darat Lainnya / Fresh }\end{array}$ & $\mathbf{2}$ & $4,661,335$ \\
$\begin{array}{l}\text { Water Fisheries and Its result } \\
\text { Pertambangan dan Penggalian / Mining and Quarrying }\end{array}$ & $\mathbf{3}$ & 632,525 \\
$\begin{array}{l}\text { Industri Pengeringan/Penggaraman ikan / } \\
\text { Drying and Salting processing and industries }\end{array}$ & $\mathbf{4}$ & $133,832,951$ \\
$\begin{array}{l}\text { Industri Pengolahan dan Pengawetan Ikan / } \\
\text { Processing and Preserving Industries }\end{array}$ & $\mathbf{5}$ & $1,336,809$ \\
Industri Pengolahan Hasil Perikanan Non Perikanan / & $\mathbf{6}$ & $9,179,112$ \\
$\begin{array}{l}\text { Agriculture Non Fisheries Processing Industries } \\
\text { Industri Pengolahan Lainnya / Other Processing Industries }\end{array}$ & $\mathbf{7}$ & $206,908,492$ \\
Jasa-jasa dan Lainnya / Services and Others & $\mathbf{8}$ & $278,376,383$ \\
\hline
\end{tabular}

Lampiran 2. Kontribusi Ekspor Terhadap Pendapatan Masyarakat Tahun 2000 Appendix 2. Export Contribution to Social Income in 2000

\begin{tabular}{|c|c|c|}
\hline Deskripsi / Description & $\begin{array}{l}\text { Sektor I } \\
\text { Sector }\end{array}$ & $\begin{array}{l}\text { Jumlah (Rp) I } \\
\text { Amount (RP) }\end{array}$ \\
\hline $\begin{array}{l}\text { Pertanian Non Perikanan / Agriculture Non Fisheries } \\
\text { Perikanan Laut dan Hasil Perairan Laut Lainnya / Marine }\end{array}$ & 1 & $13,712,135$ \\
\hline $\begin{array}{l}\text { Fisheries and Its Result } \\
\text { Perikanan Darat dan Hasil Perairan Darat Lainnya / Fresh Water }\end{array}$ & 2 & 921,027 \\
\hline Fisheries and Its Result & 3 & 121,697 \\
\hline $\begin{array}{l}\text { Pertambangan dan Penggalian / Mining and Quarrying } \\
\text { Industri Pengeringan/penggaraman ikan / }\end{array}$ & 4 & $20,423,610$ \\
\hline $\begin{array}{l}\text { Drying and Salting Processing and Industries } \\
\text { Industri Pengolahan dan Pengawetan ikan / Processing and }\end{array}$ & 5 & 198,119 \\
\hline $\begin{array}{l}\text { Preserving Industries } \\
\text { Industri Pengolahan Hasil Perikanan Non Perikanan / }\end{array}$ & 6 & $1,396,163$ \\
\hline Agriculture Non Fisheries Processing Industries & 7 & $62,279,734$ \\
\hline Industri Pengolahan Lainnya / Other processing industries & 8 & $74,195,970$ \\
\hline Jasa-jasa dan Lainnya / Services and Others & 9 & $85,249,091$ \\
\hline
\end{tabular}


Lampiran 3. Kontribusi Ekspor Terhadap Penyerapan Tenaga Kerja Tahun 2000 Appendix 3. Export Contribution to Absorption of Labor in 2000

\begin{tabular}{lcr}
\hline \multicolumn{1}{c}{ Deskripsi / Description } & Sektor / Sector & $\begin{array}{c}\text { Jumlah (Orang) I } \\
\text { Amount (people) }\end{array}$ \\
\hline $\begin{array}{l}\text { Pertanian Non Perikanan / Agriculture Non Fisheries } \\
\text { Perikanan Laut dan Hasil Perairan Laut Lainnya / }\end{array}$ & $\mathbf{1}$ & $9,736,889$ \\
Marine Fisheries and its result & $\mathbf{2}$ & 188,058 \\
Perikanan darat dan hasil perairan darat lainnya / & $\mathbf{3}$ & 12,052 \\
Fresh Water Fisheries and Its Result & $\mathbf{4}$ & 561,636 \\
Pertambangan dan Penggalian / Mining and Quarrying & $\mathbf{5}$ & 2,113 \\
Industri Pengeringan/Penggaraman Ikan / & & 30,536 \\
$\begin{array}{l}\text { Drying and Salting Processing and Industries } \\
\text { Industri Pengolahan dan Pengawetan Ikan / }\end{array}$ & $\mathbf{6}$ & $1,110,573$ \\
Processing and Preserving Industries & $\mathbf{7}$ & $4,572,001$ \\
Industri Pengolahan Hasil Perikanan Non Perikanan / & $\mathbf{8}$ & $7,954,195$ \\
Agriculture Non Fisheries Processing Industries & $\mathbf{9}$ & \\
Industri Pengolahan Lainnya / Other Processing Industries & & \\
Jasa-jasa dan Lainnya / Services and Others & &
\end{tabular}

